\title{
The Effect of Psychodrama Integrated Psycho-Education Program on Resilience and Divorce Adjustment of Children of Divorced Families
}

\author{
Ugur Gurgan ${ }^{1, *}$ \\ ${ }^{1}$ Necatibey Education Faculty, Balikesir University, Balikesir, 10145, Turkey \\ *Correspondence: Necatibey Education Faculty, Balikesir University, Balikesir, 10145, Turkey. Tel: \\ 90-266-241-2762. E-mail: ugurgan@hotmail.com
}

Received: December 24, 2019

Accepted: February 1, $2020 \quad$ Online Published: February 14, 2020

doi:10.5430/wje.v10n1p56

URL: https://doi.org/10.5430/wje.v10n1p56

\begin{abstract}
The aim of this study is to determine the effect of Psycho-drama Integrated Psycho-Education Program (PIPP) on divorce adaptation and resilience scores of children of divorced families. In this study, a $2 \times 3$ design with experimental and control groups and having pre-test, post-test and follow-up measurements was used. Nonparametric statistics were used in the analysis of the obtained data. Mann Whitney $U$ test was adopted to determine the significance of the difference between the groups and Wilcoxon Signed-Ranks Test was utilized to find the significance of the difference between the measurements. The Child's Divorce Adjustment Inventory, Child and Youth Resilience Measure and Personal Information Form were used as data collection tools. Based on the results, it was seen that the PIPP had a highly significant effect on the increase in adaptation and resilience scores of children of divorced families and this effect was long-lasting.
\end{abstract}

Keywords: psycho-education program, adjustment to divorce, resilience, psychological group counseling

\section{Introduction}

Family is a structure of individuals who have biological or psychological ties and have historical, emotional and economic unity and feel themselves as members of the same house (Gladding, 2019). The differentiation of the perspective towards marriage, having children and becoming a family in societies is also related to the developments in technology. The most dramatic change in family life during the twentieth century is increasing divorce rate (Nock, 2000). Based on the official data 128 thousand couples had divorced (Turkish Statistical Institute, 2019).

Divorce is legal and emotional termination of spouses' marriages. Today, divorce rates are increasing in Turkey as in the world. The divorce process can affect all individuals in the family positively or negatively. Especially bad experiences within the family and sometimes the process itself may cause deterioration of emotional and cognitive harmonies in children (Tezcan, 2017). According to Güler (2014), divorce is an important decision that is not only limited to the separation of spouses but can also affect their remaining lives including children.

The general effects of divorce on children can be listed as;

- Children need stability and continuity in their lives. However, divorce can create a chaos in children.

- They may encounter new regulations such as new schools, new homes, new friends, and relationships with parents, diminishing living standards.

- They may experience difficulties with the quality and stability of communication with the parent without custody.

- Family members may experience communication difficulties.

- Different family members adjust to divorce at different levels. In this process, the reaction of each may be different (İbrahimoğlu, 2004).

The effects of divorce vary according to gender. In a longitudinal study examining the psycho-social effects of divorce; Huurre, Junkkari \& Aro (2006) has found that girls with divorced parents have more relational problems while boys experience behavioral problems (Richardson \& McCabe, 2001). According to another study; it is determined that the girls whose parents have divorced are more anxious than the boys of divorced families (Aral \& 
Sağlam, 2012). As a result of divorce, girls experience more psychological and relational problems, have more negative attitudes about marriage, and experience more indecision and dissatisfaction in their relationships (Huurre et al., 2006), get more introvert and suffer more from somatic complaints (Şirvanlı Özen, 1998) while boys show signs of social incompatibility, express their feelings by fighting, and reflect their anger at those who care about them. In addition, in divorced couples, if the adolescent boy stays with the father, the adaptation level of the child to divorce is higher (Kilinc, 2004).

Steinberg (2013) has reported that in the years following the divorce, the child's stay with her fellow parent may be supportive, but in the long term, maintaining the contact with both parents and double/joint custody is more accurate. For the child of divorced families who have two houses, it is important for one parent not to disparage the other in front of the child, to maintain a common sense of discipline in both houses, and to have a room where the child can feel himself/herself that he belongs to both houses. Also, it is widely believed that the child will remain with the mother after the divorce and that the communication with the father will be unhealthy or broken. However, it is seen that some fathers behave in a more sensitive way and maintain a positive parenting model after their divorce (Şahin \& Özbey, 2007). In the period after the divorce, it is determined that the children's being in contact with their fathers decreases the possibility of their having adaptation problems and have a positive effect on boys' school performance (Altunbulak \& Aydoğan, 2015).

The way children are affected by divorce may also vary according to age. While pre-school children are more worried about themselves, children who fully understand the meaning of divorce at the age of 9-10 may get the perception of loss regarding their families (Yörükoğlu, 2016). Although the most affected group of children is 5-6 year-old girls and 8-10 year-old boys, it is found that girls generally have more anxiety and relationship problems after divorce than boys (Geniş, Toker, \& Şakiroğlu, 2019).

As a result of the surveys conducted with children of divorced families, some problems that children and adolescents experience during and after the divorce are found to be; depression (Uzun, 2013), anger (Nickerson, 2003; Sharp, 2003; Türkarslan, 2007; Fiyakal1, 2008; Çekiç, 2009, Sancakl1, 2014), loneliness (Tatay, 2015); anxiety (Stacey \& McCabe, 2001; Walczak \& Burns, 2004; Wallerstein \& Lewis, 2004; Özdal \& Aral, 2005; Öztürk, 2006; Lap, 2014), parental alienation (Şen, 2014), low self-esteem (Türkmen, 2011; Emery, 2012; Yörükoğlu, 2016; Kasuto, 2017), problems at school (Türkarslan, 2007; Lap, 2014; Tatay, 2015).

Although they have no responsibility during the divorce process, the children get the most damage (Canel, 2012). After divorce, parents might ignore the needs of their children while trying to cope with their own negative feelings and sometimes even economic difficulties. The mother's coping with the stress of divorce and continuing the care of her child is an important factor in the adjustment of the child to the divorce. A feeling of inadequacy can occur in the child trying to cope with these difficulties on his/her own. Therefore, another important factor for adjustment to divorce is informing and preparing the child before the process. Children need information and explanations about the divorce process. Parents' consensus on custody is another factor affecting the child's adjustment to divorce. Parental custody increases the adjustment of the child (Öngider, 2013).

Divorce is one of the risk factors for children's mental health problems. Psychological problems, social problems and adjustment problems are more common in children of divorced families compared to other children (Çamkuşu Arifoğlu, 2006). The necessity of introducing school-based preventive programs is increasing for children whose social support has decreased after divorce. The number of programs to protect children in order to adjust to divorce has increased in the US and Europe. Thanks to the implementation of these programs, it is observed that divorce adjustment problems have decreased.

\subsection{Related Studies}

Maccoby, Buchanan, Mnookin \& Donbusch (1993) examined the adaptation problems resulting from divorce on adolescents in a two-part study. It was reported that not having the feeling of being left in the middle of the conflict between mother and the father was important in adolescents' adjustment to the divorce.

In another study conducted by Richardson \& McCabe (2001); how divorce, conflict and intimacy of parents in adolescence affect adolescents' adaptation was examined. Negative correlation was found between a high level of parental conflict and the students' adaptation and their current intimacy with their parents. Low intimacy with both parents is associated with low psychosocial adjustment in several aspects, while high intimacy with at least one parent is positively correlated with adjustment. This research emphasizes the importance of maintaining a good parent-adolescent relationship, especially for divorced families.

Aydın \& Nazlı (2014) included ninety-three couples whose divorce proceedings were continuing in eleven family 
courts in Ankara and had dispute about custody during this process and their ninety-three children in the age group of nine to twelve, it was found that the order of birth caused a significant difference $(p<0.1)$ in their divorce adjustment levels. On the other hand; gender, age, number of siblings, the person from whom the child learned the separation of his/her parent, the parent with whom he/she lives, whether he/she keep in touch with the other parent, parent's age group, parent's level of education, working status, professional help for the child and the period of the parents' separate lives cause no significant difference ( $\mathrm{p}>.05)$.

The effect of subjective well-being intervention program on university students' subjective well-being levels and stress coping styles was examined (Malkoç, 2011). It was seen that there was a significant difference between the subjective well-being pre-test and post-test scores of the students in the experimental group. Moreover, there was a significant difference between the subjective well-being post-test scores of the experimental and control groups in favor of the experimental group.

Özkan (2014) examined the relationship between adolescents' subjective well-being and the attitudes of their parents. The population of the study consists of the students studying in secondary education in Safranbolu district of Karabuk province in 2013-2014 academic year. It was found that the subjective well-being of adolescents who perceived their parents as authoritarian, negligent and tolerant was not significantly affected by the gender of adolescents. The total scores of subjective well-being of adolescents who perceived their parents as authoritarian showed a significant difference according to their gender. The subjective well-being of male adolescents who perceived their parents as authoritarian was found to be higher than female adolescents. There was a significant difference between the parental attitudes perceived by the adolescents and their subjective well-being levels $(\mathrm{p}<0.05)$. The subjective well-being of adolescents who perceived their parents as democratic and tolerant was higher than those who perceived their parents as negligent and authoritarian.

In a study consisting of 97 participants by Sen (2014), it was underlined that 69 of the participants lived in the same city with their ex-spouses, but they could not be together even with their children in the limited time specified, and that this situation might lead to alienation from the parents as well as the fact that the child and the parents might emotionally diverge from each other.

Tatay (2015) comparatively examined the levels of academic success, subjective well-being and loneliness of adolescents of fragmented and non-fragmented families. It was found that there was a significant difference between subjective well-being levels [ $\mathrm{t}(.633)=2.93, \mathrm{p}<.05]$ of adolescents of fragmented families and those of non-fragmented families. However, there was no significant difference between the subjective well-being levels of these adolescents $[t(.337)=-.352 \mathrm{p}>.05]$ in terms of gender.

Çakır (2015) examined whether the subjective well-being of high school students differ according to the variables of gender, grade level, number of close friends, number of siblings, education level of their parents, income level of the family, perceived academic success level. According to the results, there was a significant difference in high school students' subjective well-being in terms of their perceived academic success; however, there was no significant difference in terms of gender, class level, the number of close friends, the number of siblings, education level of their parents, income level of the family, parental attitudes perceived by them.

Küçükköse (2015) examined the relationship between subjective well-being levels of high school students and their trait anger, anger expression styles and stress levels. There was a negative and low-level significant relationship between subjective well-being of high school students and their trait anger, anger-in and anger-out expression styles. There was a positive and low-level significant relationship between subjective well-being of high school students and their anger control expression style. There was a significant negative and moderate significant relationship between subjective well-being of high school students and their stress levels.

\subsection{Significance of the Study}

If children do not have the opportunity to express their feelings well enough at the end of the divorce, they may have problems such as separation anxiety, depression and attention deficit in their future periods; therefore, it is important to support the child for the solutions that enable him/her to express herself/himself emotionally (Salk \& Kramer 2002).

While divorce ends the legal process between spouses, it does not end the child-parent relationship. Parental divorce causes a number of negative effects and emotions on the child. Divorce results in some positive and negative changes in the psychological, social and economic aspects of all family members' lives. Differences in life styles that come along with divorce have some impact on children. Not every child is expected to be affected from the divorce and have the same emotions, but some of the feelings that these children may experience are; shock, guilt, anger, anxiety, 
fear of being abandoned, worthlessness, meaninglessness, rejection, emptiness and longing.

Considering the life span of the experimental group in this study, these children may develop some inappropriate coping mechanisms in response to the stress and negative emotions they experienced after divorce. Some of them are smoking, alcohol, substance abuse, depression and suicide (Barrett, Farrell, Ollendick \& Dadds, 2007). The importance of this program is to help children develop positive coping strategies rather than negative coping mechanisms.

When the literature was reviewed, very little research were reached that directly dealt with emotional resilience concept and the effectiveness of cognitive behavioral therapy (CBT) based intervention methods were studied at the same time in Turkey. In addition, few experimental studies were seen which had been conducted with 5th and 6th grade students and adolescents of divorced families and where divorce adjustment and resilience were studied together. It is hoped that the results obtained in this study will make a meaningful contribution to meeting the needs in the field.

\subsection{Purpose of the Study}

The aim of this study is to determine the effect of psychodrama integrated group counseling program on divorce adjustment and resilience scores of children of divorced families. In line with the purpose of the research, the following hypotheses were put forth;

Hypothesis 1: Post-test mean scores of The Child's Divorce Adjustment Inventory (CDAI) Practices, Child and Youth Resilience Measure - Practices with Adolescents (CYRM-Y), Child and Youth Resilience Measure Practices in Primary Schools (CYRM-C) of the individuals in the experimental group were significantly higher than the pre-test mean scores.

Hypothesis 2: Post-test mean scores of CDAI Practices, CYRM-Y, CYRM-C of the students in the experimental group in which group counselling was applied were significantly higher than those of the control group students who did not participate in this program.

Hypothesis 3: There was no significant difference between the post-test and follow-up test mean scores of CDAI Practices, CYRM-Y, CYRM-C of the students in the experimental group undergoing Psychological Group Counselling.

Hypothesis 4: There was no significant difference between the pre-test and post-test mean scores of

CDAI Practices, CYRM-Y, CYRM-C of the individuals in the control group undergoing Psychological Group Counselling.

\section{Method}

This research is an experimental study with pre-test and post-test control groups (Split plot) aiming to determine the effectiveness of Psychological Group Counseling for Children on divorce adjustment and resilience. The independent variable of the research is "Psychological Group Counseling" and the dependent variable is level of divorce adjustment, subjective well-being and resilience.

\subsection{Research Design}

In this study, pre-test and post-test control group experimental design was used. The design of the study is presented in Table 1.

Table 1. Experimental Design of Research

\begin{tabular}{llllll}
\hline Groups & Placement & Pre-Test & Procedure & Post-Test & Follow-Up Test \\
\hline Experimental & Randomly & CDAI Practices & Psychological & CDAI Practices & CDAI Practices \\
& assigned & CYRM - Y & Group & CYRM - Y & CYRM - Y \\
& & CYRM - C & Counseling & CYRM - C & CYRM - C \\
\multirow{5}{*}{ Control } & Randomly & CDAI Practices & --- & CDAI Practices & CDAI Practices \\
& \multirow{2}{*}{ assigned } & CYRM - Y & & CYRM - Y & CYRM - Y \\
& & CYRM - C & & CYRM - C & CYRM - C \\
\hline
\end{tabular}




\subsection{Participants}

The individuals included in the study including the children of divorced families and their parents were identified by purposeful sampling. They were studying in formal secondary schools in Balikesir city center. Written and oral announcements were made at primary, secondary and high schools in the city center the content of the training program was introduced and calls were made to the children wishing to participate. It was taken into consideration that the students did not have any significant psychological problems and did not use any medication that would affect the process. Information was given to the students about the content of the program through pre-interview with the students wishing to participate in the program. Then, 83 students who were willing to participate in the Psychological Group Counseling Program with the consent of their parents were administered CDAI, CYRM-Y and CYRM-C. Out of 28 students who completed the scale and measurements completely, 14 (50\%) were randomly assigned to the experimental group while $14(50 \%)$ were assigned to the control group. The criteria for participating in the research within the scope of purposive sampling are: 1 . At least 6 months should have passed following the divorce process; 2. To study in formal secondary schools in Balikesir city center in 2018-2019 academic year, 3. To participate voluntarily in the research with the consent of their parents. Twelve (42.9\%) of the participants were girls, 6 of whom were in the experimental group and 6 of whom were in the control group. 12 children in the experimental group were 5 th graders while 16 of them are in 6th grade.

In order to test the effectiveness of the program applied in the research, it is necessary to determine that there is no significant difference between the groups in terms of the studied variable at the beginning of the experimental process. For this purpose, it was determined by using Mann Whitney $U$ test that the experimental and control groups were not different from each other according to the data collection tools before the program and the results are presented in Table 2.

Table 2. Mann Whitney U Test Results of Group Scores before Psychological Group Counseling

\begin{tabular}{lllllll}
\hline Data Collection Tool & Groups & $\mathrm{n}$ & Mean Rank & Rank Sum & $\mathrm{U}$ & $\mathrm{p}$ \\
\hline CDAI & Experimental & 14 & 12,96 & 181,50 & 76,5 & .32 \\
& Control & 14 & 16,04 & 224,50 & & \multirow{2}{*}{, 45} \\
CYRM - Y & Experimental & 14 & 13,32 & 186,50 & 81,5 & \multirow{2}{*}{68} \\
& Control & 14 & 15,68 & 219,50 & & 89 \\
CYRM - C & Experimental & 14 & 15,14 & 212,00 & & \\
& Control & 14 & 13,86 & 194,00 & & \\
\hline
\end{tabular}

As can be seen in Table 2, the scores obtained by the individuals before the Psychological Group Counseling Program were not significantly different in terms of the groups. This result shows that the experimental and control groups were statistically equal before the program $(\mathrm{CDAI}=76.5, \mathrm{p}>.05 ; \mathrm{CYRM}-\mathrm{Y}=81.5, \mathrm{p}>.05 ; \mathrm{CYRM}-\mathrm{C}=89$, $\mathrm{p}>.05)$.

\subsection{Data Collection Tools}

\subsubsection{Personal Information Form (PIF)}

A personal information form was developed by the researcher to collect information about the socio-demographic variables of the study. In the questionnaire, variables related to age, gender, class, number of siblings, educational level of the parents, income, time passed following the divorce of the parents and presence of a step-parent which were thought to be related to the divorce adjustment status of the children were given (Table 1).

\subsubsection{The Child's Divorce Adjustment Inventory (CDAI)}

The Child's Divorce Adjustment Inventory (CDAI) was developed by Portes, Lehman and Brown (1999) and its validity and reliability studies were conducted by Çamkuşu Arifoğlu (2006). The inventory consists of 22 items and 3 dimensions. There are three sub-dimensions: conflict-poor adjustment, depression-anxiety and social support. As a result of the evaluation of the inventory, a single score is obtained from the whole inventory and this score indicates the adjustment of the children to divorce. The lowest score that can be obtained from the scale without any cut-off score is 22 and the highest score is 110. It is concluded that child's adjustment to divorce increases as the score increases (Arifoğlu, Razı, Şanlı Richard, \& Öz, 2010). In the reliability study conducted for the Turkish version of CDAI; The Cronbach's Alpha reliability value of the inventory was 0.70 and the test-retest reliability was 0.66 . In this study, Cronbach's Alpha coefficient of the scale was found to be 0.68 (Arifoğlu et al., 2010).

\subsubsection{Child's and Youth Resilience Measure (CYRM-C/Y)}

The Child and Youth Psychological Resilience Scale was developed by Liebenberg, Ungar and Van de Vijver (2012). 
The original form of the scale, which was developed in the light of data collected from 11 different countries, consists of three sub-scales and eight sub-dimensions. The short form study of the scale was conducted by Liebenberg, Ungar and LeBlanc (2013) and a structure of 12 items was obtained as a result of two different studies. Factor load values of the scale varied between 0.39 and 0.88 and internal consistency coefficient was 0.84 . The high scores obtained from the scale, which was a Likert type measuring instrument consisting of 12 items, indicated high level of resilience. The scale was adapted into Turkish by Arslan (2015). In the validity study of the scale carried out with 11-16 age groups, the results of the factor analysis showed that the scale had a single factor explaining $51.28 \%$ of the total variance. In the criterion validity of the scale, positive-negative emotions and self-efficacy were used. There was a significant relationship between CYRM and positive emotions, negative emotions and self-efficacy in the level of $0.57,-0.39$ and 0.45 respectively. Cronbach's Alpha internal consistency coefficient of the scale was calculated as 0.91 . Item-total correlation values of the scale ranged between 0.45 and 0.79 . In this study, Cronbach's Alpha coefficient of the scale was found to be 0.81 .

\subsubsection{The Child's Divorce Adjustment and Resilience Psychological Group Counseling Program}

This study was carried out on children of divorced families which was a disadvantaged group that would create risks for negative emotions and behaviors in many respects. The study was carried out in a way that it was sensitive to the culture of the study and in three dimensions, providing conscious awareness, supporting both positive development and preventing the growth of pathological problems. The levels of competencies areas and outcomes were identified for each session of the program.

When creating the Psychodrama Integrated Psychological Group Counseling Program; emprical studies on adjustment and resilience carried out by Dursun, (2015), Eryılmaz, (2017), Balc1, (2018), Erkan (2018) and Morganett (2018) were also benefitted from. In addition, the theoretical background of the study was determined by examining the experimental studies on the issues such as anger, anxiety, low motivation, low self-esteem, hopelessness and so on which were the most outstanding emotions experienced after the divorce process in the literature. Consequently, it was decided to utilize theories and approaches such as cognitive behavioral therapy, rational-emotional therapy, reality therapy, positive psychotherapy, and psychodrama. Finally, the program was a psychological group counseling program with an eclectic group integrated with psychodrama prepared by benefiting from different therapy theories and approaches.

The program was developed to support resilience, social skills and positive coping characteristics of children and adolescents. The training consisted of structured experimental and integrative sessions. In this training, it was aimed to help the children gain the competence of practitioners in the following topics. 10 sessions of child-adolescent session structuring were: greeting, psychological resilience, social skills development, mind theory, cognitive and psychological flexibility, empathy, humor, autonomy, problem solving, stress management, negative thought hunter, return to the future, technique of role reversal, learning relaxation exercises. In addition, except for the first two sessions, there were homework assignments based on cognitive behavioral approach. Educational and entertaining activities had been developed to help children and adolescents felt well about divorce adjustment.

Moreover, techniques such as painting, questioning negative automatic thoughts and emotion thermometers as well as the approaches such as Eye Movement Desensitization and Reprocessing (EMDR), CBT, Psychodrama were applied. Some of the games used in the psycho-education program were: Deadlock, snowball, write and burn, garlic and onion, an imaginary mirror, plug game, seller-customer game, don't burst out the inflated balloon, love bombing, station technique, bus ride game and three events that make me happy, worry anxiety story writing, safe place and so on. In addition, some materials were used in the program. These materials were: "Divorce thoughts scale-short form", "What kind of person am I?", "Mental control writing", Anxiety diary keeping.

\subsubsection{Summary of Psychological Group Counseling Program Sessions}

In the first session, activities such as participants' greeting, informing the group about the psychological counseling process, determining group rules, creating expectations for the group and creating goals in this direction, participants' expressing how it feels like to live in a divorced family, providing catharsis, and the positive and negative effects of divorce on children were focused on.

In the second session, sharing the differences in life patterns arising from divorce and the normalization of emotions, sharing of positive aspects of divorce for parents and children -if any- in the group, emphasizing the importance of different strategies in the solution of problems and the importance of getting help, the events that they perceive as the breaking point in their lives, to help them express themselves took place.

In the third session, it was aimed to start processing the relationships between emotions, thoughts and behaviors in 
line with cognitive therapy, to help them realize which thoughts form emotions and what behaviors are acted with these emotions.

In the fourth session, it was aimed to realize that there were individuals with different experiences and perspectives about divorce and to help remove the negative memories about divorce out of their minds with EMDR therapy techniques.

In the fifth session, it was aimed to improve the self-concept of the counselees by enabling them to express their positive characteristics and share positive things about themselves and to receive positive feedback from others. The counselees were helped to admit that they were people with characteristics that would enable them to think positively about themselves even if their families had problems.

In the sixth session, it was aimed to express the definition and types of communication, to express how the communication barriers could be reflected in the relations, to make the members aware of the communication barriers in their relations with their parents.

In the seventh session, it was aimed to work on the reasons for rage and to express that anger was neither good nor bad, to help students recognize their unique reaction patterns when they were angry and to teach them how to control anger and suitable ways to express their anger.

The eighth session focused on the consequences of changing the members' intermediate beliefs, connected faulty thoughts and feelings. It aimed to give the opportunity for the members to express their feelings and thoughts about the process of automatic and irrational change of thoughts.

The aims of the ninth and tenth sessions were to enable individuals to integrate all the skills they had learned during the program into their daily lives and continue to use the skills they gained. In the last session, the eleventh session, psycho-education was evaluated, unfinished works were finalized. Later on, they said goodbye after love bombing, strengthening positive self-esteem, sharing positive feelings and thoughts.

In addition, throughout the process, the purpose of the session in which the participant participate was briefly explained, the members were asked how they had spent the week, their feelings and thoughts about the issues discussed in the last session were asked, the members who were willing to evaluate the previous session briefly, the questions of the participants -if any- were answered, and the members received positive feedback and also the subject and date of the next session was determined.

\subsubsection{Experimental Group Practices}

In this study, an eclectic psycho-education program consisting of 11 sessions, each lasting approximately two hours, was established with the individuals in the experimental group. Before the sessions started, a meeting was held with the members of the group and their parents and their consent was obtained for the students to join the group. Parents were also allowed to sign their petitions. Then, the group rules were explained to the students and the forms with the rules were handed out. Sessions are scheduled for one session per week. The sessions were conducted outside the school hours under the leadership of the researcher.

\subsubsection{Data Analysis}

In order to determine the effect of "Psycho-Drama Integrated Psychological Group Counseling" applied to the experimental group, the assumptions of parametric statistical techniques could not be met due to the small number of individuals forming the experimental and control groups. Therefore, nonparametric statistical techniques were used in the analysis of the data. Mann Whitney $U$ test was adopted to test the significance of the difference between the groups and Wilcoxon Signed Ranks test was used to test the significance of the difference between the measurements.

\section{Results}

Under this heading, the quantitative findings obtained from the CDAI, CYRM-Y and CYRM-C were used to identify the differences between the experimental and control groups. The findings were presented below in the order of the tests. 
Table 3. Wilcoxon Signed-Ranks Test Results Regarding CDAI, CYRM-Y, CYRM-C Pre-Test and Post-Test Scores of Experimental Group

\begin{tabular}{lllllll}
\hline Tool & Post-test Pre-Test & $\mathrm{N}$ & Mean Rank & Rank Sum & $\mathrm{Z}$ & $\mathrm{p}$ \\
\hline CDAI & Negative Rank & 0 & 0,00 &, 00 & $-3,298$ & $.001^{*}$ \\
& Positive Rank & 14 & 7,50 & 105,00 & & $.045^{*}$ \\
& Equal & 0 & & & & \\
& Negative Rank & 4 & 4,25 & 17,00 & $-2,001$ & $.001^{*}$ \\
CYRM-Y & Positive Rank & 9 & 8,22 & 74,00 & & $-3,296$ \\
& Equal & 1 & & & \\
& Negative Rank & 0 &, 00 & 105,00 & & \\
CYRM-C & Positive Rank & 14 & 7,50 & & & \\
& Equal & 0 & & & & \\
\hline
\end{tabular}

$* \mathrm{p}<. \overline{05}$

To test Hypothesis 1, Wilcoxon Signed Ranks Test was applied on the pre-test and post-test scores of the individuals in the experimental group and the results were given in Table 3. The results of the statistical analysis in Table 3 showed that there was a significant difference between the pre-test and post-test scores of the individuals in the experimental group (ZCDAI $=-3,298, p<.001$; ZCYRM-Y $=-2,001, p<.045$; ZCYRM-C $=-3,296, p<.001$ ). In this case, the hypothesis: "Post-test mean scores of CDAI Practices, CYRM-Y, CYRM-C of the individuals in the experimental group undergoing Psychological Group Counseling Program were significantly higher than the pre-test mean scores." was verified. When the rank sums of the difference points were taken into consideration, it was seen that this difference was in favor of the positive rankings, in other words, the post-test score. In this case, Psychodrama-integrated Psychological Group Counseling was effective in increasing individuals' adjustment and resilience to divorce.

To test Hypothesis 2, Mann Whitney U test was applied on the post-test scores of the students in the experimental and control groups and the results were given in Table 4.

Table 4. Mann Whitney U Test Results Regarding CDAI, CYRM-Y, CYRM-C Post-Test Scores of Experimental and Control Groups

\begin{tabular}{lllllll}
\hline Tool & Groups & $\mathrm{N}$ & Mean Rank & Rank Sum & $\mathrm{U}$ & $\mathrm{p}$ \\
\hline CDAI & Experimental & 14 & 21,50 & 301,00 & 0,00 & $.000^{*}$ \\
& Control & 14 & 7,50 & 105,00 & & \\
CYRM-Y & Experimental & 14 & 14,14 & 198,00 & 46,00 & $.016^{*}$ \\
& Control & 14 & 14,86 & 208,00 & & \\
CYRM-C & Experimental & 14 & 19,14 & 268,00 & 33,00 & $.003^{*}$ \\
& Control & 14 & 9,86 & 138,00 & & \\
\hline .05 & & & & & &
\end{tabular}

As seen in Table 4, there was a significant difference in favor of the experimental group between the post-test scores of the experimental and control groups (UCDAI $=0, p<.05$; UCYRM-Y $=46, p<.05$; UCYRM-C $=33, p<.05$ ). In this case, the hypothesis: "CDAI, CYRM-Y and CYRM-C post-test average scores of the individuals in the experimental group undergoing Psychodrama-integrated Psychological Group Counseling Program is significantly higher than the post-test average scores of the control group students who haven't participated in this program" was verified. When the mean ranks were examined, it was seen that the students who participated in psychological group counseling had higher levels of adjustment to divorce, higher subjective well-being and resilience than the students who hadn't participated in this program.

To test Hypothesis 3, Wilcoxon Signed Ranks Test was applied on the post-test and follow-up test scores of the individuals in the experimental group and the results were given in Table 5. 
Table 5. Wilcoxon Signed-Ranks Test Results Regarding CDAI, CYRM-Y, CYRM-C Post-Test and Follow-Up Test Scores of Experimental Group

\begin{tabular}{|c|c|c|c|c|c|c|}
\hline Tool & $\begin{array}{l}\text { Post-Test } \\
\text { Follow-Up }\end{array}$ & $\mathrm{N}$ & Mean Rank & Rank Sum & $\mathrm{Z}$ & $\mathrm{p}$ \\
\hline \multirow[t]{4}{*}{ CDAI } & Negative Rank & 15 & 14,13 & 212,00 & $-2,121$ & $.021^{*}$ \\
\hline & Positive Rank & 8 & 8,00 & 64,00 & & \\
\hline & Equal & 5 & & & & \\
\hline & Negative Rank & 10 & 11,05 & 110,50 & $-1,131$ & .258 \\
\hline \multirow[t]{2}{*}{ CYRM-Y } & Positive Rank & 8 & 7,56 & 60,50 & & \\
\hline & Equal & 10 & & & & \\
\hline \multirow[t]{3}{*}{ CYRM-C } & Negative Rank & 15 & 16,17 & 242,50 & $-1,304$ & .192 \\
\hline & Positive Rank & 12 & 11,29 & 135,50 & & \\
\hline & Equal & 1 & & & & \\
\hline
\end{tabular}

The results of Wilcoxon Signed Ranks Test for the post-test and follow-up test scores of the experimental group were shown in Table 5. There was a significant difference between the mean scores of the follow-up test and the post-test obtained by the individuals in the experimental group in favor of CDAI but there was no significant difference between the mean scores of other scales. (ZCDAI =-2,121, $\mathrm{p}<.05$; ZCYRM-Y=-1,131, p>.05; ZCYRM-C $=-1,304$, $\mathrm{p}>.05$ ). Therefore, The hypothesis: "There was no significant difference between the post-test and follow-up test mean scores of CDAI Practices, CYRM-Y, CYRM-C of the students in the experimental group undergoing Psychological Group Counseling." wasn't verified. This result showed that the effect of the Psychodrama integrated Psychological Group Counseling Program applied to the experimental group was not permanent in terms of adjustment to divorce but it was permanent in terms of resilience.

To test Hypothesis 3, Wilcoxon Signed Ranks Test was applied on the pre-test and post-test scores of the control group and the results were given in Table 6.

Table 6. Wilcoxon Signed-Ranks Test Results Regarding CDAI, CYRM-Y, CYRM-C Pre-Test and Post-Test Scores of Control Group

\begin{tabular}{lllllll}
\hline Tool & Post-Test Pre-Test & N & Mean Rank & Rank Sum & Z & P \\
\hline CDAI & Negative Rank & 7 & 7,71 & 54,00 & $-1,890$ & .06 \\
& Positive Rank & 4 & 3,00 & 12,00 & & \\
& Equal & 3 & & 55,50 & $-1,027$ & .31 \\
& Negative Rank & 8 & 6,94 & 10,50 & & \\
CYRM-Y & Positive Rank & 3 & 3,50 & & & \\
& Equal & $3^{1}$ & & 40,00 & & \\
CYRM-C & Negative Rank & 6 & 6,67 & 51,00 & & \\
& Positive Rank & 7 & 7,29 & & & \\
& Equal & 1 & & & & \\
\end{tabular}

As seen in Table 6, there was no significant difference between the pre-test and post-test mean scores of the individuals in the control group (ZCDAI $=-1,890, \mathrm{p}>.05 ; \mathrm{ZCYRM}-\mathrm{Y}=-1,027, \mathrm{p}>.05 ; \mathrm{ZCYRM}-\mathrm{C}=-, 385, \mathrm{p}>.05$ ). Thus, the hypothesis: "There was no significant difference between the pre-test and post-test mean scores of CDAI Practices, CYRM-Y, CYRM-C of the individuals in the control group undergoing Psychological Group Counseling." was verified.

As a result, research findings showed that participation in Psychodrama-integrated Group Counseling was effective in increasing the adjustment and resilience levels of individuals to divorce. It was seen that there was a significant increase in the scores of CDAI, CYRM-Y and CYRM-C of the participants undergoing Psychological Group Counseling Program compared to the individuals who did not.

\section{Discussion}

In this study, "Psycho-drama Integrated Psychological Group Counseling" is found to be effective in increasing individuals' adjustment levels and resilience to divorce. CDAI post-test scores of the students in the experimental group in which psychological group counseling was applied were significantly higher than the post-test scores of the 
students in the control group who did not participate in this program. These results were consistent with Çamkuşu Arifoğlu (2006) and Meriç (2007) who reported that group guidance program increases the general adjustment level/levels of the experimental groups.

Results of this study also demonstrates that the social support that children and adolescents in the experimental group whose parents had divorced gave to each other during the psychological counseling program also contributed positively to their self-esteem and this contribution increased their subjective well-being levels. Similar results are also reported by Terzi (2008) and Güney (2019) who found a positive correlation between social support and psychological resilience. However, the result of this study is much significant and unique since it works with risk group such as children and adolescents of divorced families.

Sessions and activities aimed at eliminating the negative effects of divorce, controlling anger and reducing anxiety were handled with a pathology-oriented approach. Sessions and activities to foster forgiveness, self-esteem, and hope were carried out with a positive psychology approach. The results indicate an effective process and approach in terms of fostering adjustment to divorce and development of resilience which enables an improvement for future group studies. Children and adolescents' participating in the study became an important psychological support point for them to confront with the negative effects of divorce, understand the process of divorce, be aware of their internal and external protective environment and learn how to benefit from them. The increase in resilience level in the quantitative findings of the study and the observation that positive emotions were experienced in a balanced way instead of the negative emotions at the beginning of the study support this conclusion. It was observed that the demotivation of the adolescents of divorced parents resulting when they couldn't perceive the connection between their own actions and their results was reduced by gaining insight into their feelings, thoughts and behaviors during the sessions.

Forgiveness is described as a person's knowingly and willfully giving up the negative feelings such as rage, anger and revenge; and instead trying to foster positive reactions such as mercy, generousness and helpfulness (Enright $\&$ Fitzgibbons, 2000). It is known to cause an increase in physical and psychological well-being of a person by increasing his/her positive emotions and reducing the negative ones (McCullough \& Witvliet, 2002). At the end of the forgiveness session of this study, it was stated that adolescents' positive emotions increased and negative emotions decreased relatively. Thus, this study shows that forgiveness for the adolescents of divorced families is an effective method of increasing resilience and increasing well-being as a consequence.

One of the problems in adolescence is the inability to set goals. When the effects of divorce are added on this period, it can become more complicated. However, it is known that people with high resilience are more successful in setting goals and motivation to achieve goals (Werner \& Smith, 1992; Masten, 1994; Kumpfer, 1999; Mandleco \& Peery, 2000; Olsson, Bond, Burns, Vella-Brodrick, \& Sawyer, 2003). When this finding was evaluated, it could be said that one of the factors that increased resilience was that individuals turn towards the goals appropriate for them (Gürgan, 2006). According to self-determination theory, the goal setting of an individual increases his/her positive emotions and decreases the negative ones (Ryan \& Deci, 2000). At the end of the psycho-education program implemented in this study, it was understood from the responses of children and adolescents to the scales of resilience and divorce adjustment that they understood the importance of setting goals.

Finally, it can be said that the above mentioned advantages of psychological group counseling are in a good accordance with literature. When the data gathered through interviews, it is seen that adolescents felt themselves better by satisfying their needs for belonging.

\section{Conclusions}

In this study, it was seen that psychological group counseling practice increased adolescents' adjustment to divorce and their subjective well-being. At the same time, the feedback from the students and teachers indicated that psychological group counseling was effective in the adolescents' communication within the family and expressing their feelings. Also, positive psychology and pathological mental health services were tried to be integrated in this study. In this respect, the following conclusions and suggestions are driven:

It is considered that the continuous practice of psychological group counseling by the school guidance services will be beneficial for the psycho-social development of adolescents. During the preparation phase of the psychological group counseling program for the children of divorced families, it was found that there was not enough work done on this issue in Turkey. Programs aimed at strengthening the adjustment and psychological resilience of children and adolescents should be increased in number and school psychological counselors should be trained on this issue. 
Precautions should be taken for healthy development of the child and behaviors other than displaying an overprotective attitude to the child should be avoided.

Within the scope of this research, the Psychological Group Counseling Program focused on adaptation to the new situation after divorce, emotional awareness, communication, anger control and awareness of one's own positive characteristics, psychological endurance, empathy, positive self-perception. It may be beneficial to work on stress coping and problem solving skills in the psycho-education programs to be developed from now on.

In terms of indirect guidance services, it may be beneficial to include family education activities to help them adjust to divorce as well as to help the children and adolescents apply the skills gained during the psychological group counseling process. The dimension of family participation in psycho-education programs for the adolescents and children of divorced families may also be included.

\section{Acknowledgement}

This study was supported by Balıkesir University Scientific Research Projects Coordination Unit, Project No: 2018/117. (Bu çalışma Balıkesir Üniversitesi Bilimsel Araştırma Projeleri Birimi tarafından desteklenmiştir, Proje No: 2018/117)

\section{References}

Aral, N., \& Sağlam, M. (2012). The examination of the emotions in terms of gender of the children whose parents are in the process of divorce and the children who live with their parents. Journal of Ankara Health Sciences, 1(2), 72-85. http://dx.doi.org/10.1501/Asbd_0000000019

Arifoğlu, B., Şanlı Richard, N., Razı, G., \& Öz, F. (2010). The child's divorce adjustment inventory: A study of validity and reliability. Turk J Child Adolesc Ment Health, 17(3), 121-127.

Arslan, G. (2015). Psychometric properties of child and youth resilience measure (CYRM-12): The study of reliability and validity. Ege Journal of Education, 16(1), 1-12. https://doi.org/10.12984/eed.23397

Aydın, R. Ş., \& Nazlı, S. (2014). Examination of life skills education program's efect to adjustment level on divorced families' children. Journal of Social Policy Studies, 33, 127-153. http://dx.doi.org/10.21560/spcd.81402

Balc1, İ. (2018). The effect of childhood traumatic experiences on resilience and depression symptoms (Unpublished doctoral dissertation). K. Technical Univ., Trabzon.

Barrett, P. M., Farrell, L. J., Ollendick, T. H., \& Dadds, M. (2007). Long-term outcomes of an Australian universal prevention trial of anxiety and depression symptoms in children and youth: An evaluation of the Friends Program. https://doi.org/10.1207/s15374424jccp3503_5

Çakır, G. (2015). A study on the high school students' subjective well-being levels in terms of some variables (Unpublished master's dissertation). Dokuz Eylul University, İzmir.

Çamkuşu Arifoğlu, B. (2006). The effect of "the children's divorce adjustment program (CDAI)" on children's adjustment to divorce, anxiety and depression level (Unpublished doctoral dissertation). Hacettepe Univ., Ankara.

Çekiç, A. (2009). The effect of group counselling on helping anger management skills of second grade student at primary education (Unpublished master's dissertation). Gaziantep University, Gaziantep.

Dursun, A. (2015). The effectiveness of a program that increases subjective well - being of adolescents whose parents are divorced (Unpublished master's dissertation). Osmangazi University, Eskişehir.

Emery, E. R. (2012). Marriage, Divorce, and Children's Adjustment. (E. O. Gezmiş, Trans.). İstanbul: İşbank. Yay.

Enright, R. D., \& Fitzgibbons, R. P. (2000). Helping clients forgive: An empirical guide for resolving anger and restoring hope. Washington: APA. https://doi.org/10.1037/10381-000

Eryllmaz, A. (2017). The effectiveness of a peer-helping programme that increases subjective well-being. British Journal of Guidance \& Counselling, 45(3), 225-237. https://doi.org/10.1080/03069885.2015.1057473

Fiyakalı, N. C. (2008). The comparision of the trait anger and anger expression styles of the high school students with divorced and nondivorced parents (Unpublished master's dissertation). Pamukkale University, Denizli.

Geniş, M., Toker, B., \& Şakiroğlu, M. (2019). Effect of divorce on children, expression to the child and parental alienation: Review study. Journal of Adnan Menderes Univ. Health Sciences Faculty, 3(3), 190-199. 
Gladding, S. T. (2019). Family therapy: History, theory, and practice. (İ. Keklik \& İ. Yildirim Trans. Eds.). Ankara: Türk PDRDER Yayınları.

Güler, F. (2014). Investigation of self-esteem depression and perception of acception-rejection of children in divorce process with respect to various variables (Unpublished master's dissertation). Ankara University, Ankara.

Gürgân, U. (2006). The Effect of the group program of resiliency level of university students (Unpublished doctoral dissertation). Ankara University, Ankara.

Huurre, T., Junkkari, H., \& Aro, H. (2006). Long-term psychosocial effects of parental divorce. Eur Arch Psychiatry Clin Neurosci, 256(4), 256-263. https://doi.org/10.1007/s00406-006-0641-y

İbrahimoğlu, D. (2004). The right choice in marriage happiness in the family. İstanbul: Hayat Yayıncılık.

Kasuto, M. (2017). The assessment of self-esteem and mental health variables of the parental divorce children in comparison to the non-parental divorce children (Unpublished master's dissertation). Iş1k University, İstanbul.

Küçükköse, İ. (2015). Examining of relationship between their levels of trait anger, anger expression styles and stress with high school students's subjective well-being levels (Unpublished master's dissertation). Mevlana Univ., Konya.

Kumpfer, K. L. (1999). Factors and processes contributing to resilience: The resilience framework. In M. D. Glantz \& J. L. Johnson (Eds.), longitudinal research in the social and behavioral sciences. Resilience and development: Positive life adaptations (pp. 179-224). Kluwer Academic Publishers. https://doi.org/10.1007/0-306-47167-1_9

Lap, F. (2014). Child in the process of divorce. Popular Journal of Psychiatry, 78, 14-17.

Liebenberg, L., Ungar, M. T., \& LeBlanc, J. C. (2013). The CYRM-12: A brief measure of resilience. Canadian Journal of Public Health, 104(2), 131-135. https://doi.org/10.17269/cjph.104.3657

Liebenberg, L., Ungar, M., \& Van de Vijver, F. R. R. (2012). Validation of the child and youth resilience measure-28 (CYRM-28) among Canadian youth with complex needs. Research on Social Work Practice, 22(2), 219-226. https://doi.org/10.1177/1049731511428619

Maccoby, E. E., Buchanan, C. M., Mnookin, R. H., \& Dornbusch, S. M. (1993). Postdivorce roles of mothers and fathers in the lives of their children. Journal of Family Psychology, 7(1), 24-38. https://doi.org/10.1037/0893-3200.7.1.24

Malkoç, A. (2011). Effectiveness of subjective well-being program on subjective well-being levels of undergraduate students (Unpublished master's dissertation). Marmara University, İstanbul.

Mandleco, B. L., \& Peery, J. C. (2000). An organizational framework for conceptualizing resilience in children. Journal of Child and Adolescent Psychiatric Nursing, 13(3), 99-111. https://doi.org/10.1111/j.1744-6171.2000.tb00086.x

Masten, A. S. (1994). Resilience in individual development: Successful adaptation despite risk and adversity. In M. C. Wang \& E. W. Gordon (Eds.), Educational resilience in inner city America: Challenges and prospects (pp. 3-25). Mahwah, NJ: Lawrence Erlbaum.

McCullough, M. E., \& Witvliet, C. V. (2002). The psychology of forgiveness. In C. R. Snyder and S. J. Lopez (Eds.), Handbook of Positive Psychology (pp. 446-458). New York: Oxford University Press

Meriç, B. (2007). An evaluation of a group counselling study improving adolescents' adjustment levels and social skills from divorced families (Unpublished doctoral dissertation). Marmara University, İst.

Morganett, R. S. (2018). Skills for living: Group counseling activities for elementary students (Alim Kaya, Sonay Güçray ve Mesut Saçkes, Trans.). Ankara: PegemA

Nickerson, K. F. (2003). Anger in adolescents: The effects of a brief cognitive-behavioral anger management training program for reducing attitudinal and behavioral expressions of anger (Unpublished doctoral dissertation). Capella University, Minnesota.

Nock S. L. (2000). The divorce of marriage and parenthood. Journal of Family Therapy, 22(3), $245-263$. https://doi.org/10.1111/1467-6427.00150

Olsson, C. A., Bond, L., Burns, J. M., Vella-Brodrick, D., \& Sawyer, S. M. (2003). Adelescent resilience: A concept analysis. Journal of Adolescence, 26(1), 1-11. https://doi.org/10.1016/S0140-1971(02)00118-5

Öngider, N. (2013). Effects of divorce on children. Current Approaches in Psychiatry, 5(2), $140-161$. https://doi.org/10.5455/20130510 
Özdal, F., \& Aral, N. (2005). A Study on anxiety levels of children, living with mother and father and having fatherless. Gazi Üniversitesi KırşehirĔ̈itim Fakültesi, 6(2), 255-267.

Özkan, İ. (2014). A study on the relation between parental attitude and subjective well-being in adolescents (Unpublished master's dissertation). Abant İzzet Baysal University, Bolu.

Öztürk, S. (2006). The relation between the self esteem and the anxiety levels of children between the age-9-13 whose parents had divorced and the same range of whpm are not divorced (Unpublished master's dissertation). Dokuz Eylül University, İzmir.

Portes, P. R., Lehman, A. J., \& Brown, J. H. (1999). The child adjustment inventory: Assessing transition in child divorce adjustment. Journal of Divorce \& Remarriage, 30(1-2), 37-45. http://dx.doi.org/10.1300/J087v30n01_03

Richardson, S., \& McCabe, M. P. (2001). Parental divorce during adolesence and adjustment in early adulthood. Adolescence, 36(143), 467-489.

Rosenfeld, L. R., Richman, J. M., \& Bowen, G. L. (1998). Low social support among at-risk adolescents. Children \& Schools, 20(4), 245-260. https://doi.org/10.1093/cs/20.4.245

Ryan, R. M., \& Deci, E. L. (2000). Self-determination theory and the facilitation of intrinsic motivation, social development, and well-being. American Psychologist, 55(1), 68-78. https://doi.org/10.1037/0003-066X.55.1.68

Salk, L., \& Kramer, R. (2002). A Parents' Guide to Emotional Health from Infancy through Adolescence. (E. Onur, Trans.). İstanbul: Remzi Kit.

Sancakl1, D. (2014). Divorced mothers' and their childrens' experiences about divorce process (Unpublished master's dissertation). Maltepe Üniversitesi, İstanbul.

Şen, B. (2014). Parent alienation syndrome. In H. Buker (Ed.), Children and violence: Children in the context of social violence (pp. 42-54). İstanbul: Samer Bilimsel Yay.

Sharp, S. R. (2003). Effectiveness of an anger management program based on rational emotive behavioral theory (REBT) for middle school students with behavior problems (Unpublished doctoral dissertation). The University of Tennessee, Knoxville.

Stacey, R., \& McCabe, M. P. (2001). Parental divorce during adolescence and adjustment in early adulthood. Adolescence, 36(143), 467-489.

Tatay, E. (2015). The comparison of teenagers who have unbroken or broken families in terms of academic achievement, subjective well-being and loneliness levels (Unpublished master's dissertation). Gaziosmanpaşa University, Tokat.

Tezcan, G. (2017). Comparing and investigating the personality patterns of the individuals according to marital status of their parents and demographic variables (Unpublished master's dissertation). Haliç University, İstanbul.

Türkarslan, N. (2007). The negative impacts of divorce on children and the ways to cope with them. Aile ve Toplum, 3(11), 99-108.

Türkiye, İ. K. (TUIK). (2019). Marriage and divorce statistics. Retrieved from http://www.tuik.gov.tr/PreHaberBultenleri.do?id=27593

Türkmen, M. (2011). The structure of subjective well-being and its relationship to parenting style, self esteem and social support: A model test (Unpublished doctoral dissertation). Ankara University, Ankara.

Uzun, Ç. (2013). Evaluating depression and social skills in children who have seperated parents and whose parents are still together (Unpublished master's dissertation). İstanbul Arel University, İstanbul.

Walczak, Y., \& Burns. (2004). Divorce: The child's point of view. London: Harper and Row.

Wallerstein, J. S., \& Lewis, J. M. (2004). The unexpected legancy of divorce: report of a 25 year study. Psychoanalytic Psychology, 21(3), 353-370. https://doi.org/10.1037/0736-9735.21.3.353

Werner, E. E., \& Smith, R. S. (1992). Overcoming the odds: High risk children from birth to adulthood. Ithaca, NY: Cornell Univ. Press.

Yörükoğlu, A. (2016). Child mental health: Child's personality development, education and mental problems. İst. Özgür. 